\title{
Effect of Vitamin D and Milk Protein on Child Growth and Health
}

\author{
Yimer Mihretie* \\ Department of Human Nutrition, Kotebe Metropolitan University, Ethiopia
}

*Corresponding author: Yimer Mihretie, Department of Human Nutrition, Kotebe Metropolitan University, Addis Ababa, Ethiopia.

Received Date: July 01, 2019

Published Date: July 08, 2019

\section{Opinion}

Milk protein has a lot of nutritional merits. First, it is reich in amino acids essential for growing children and maintenance of a health life. Second, it is important for enhancing immune system development that is used for strong protection of harmful organisms. Milk protein can be classified into casein protein, whey protein and their derivative polypeptides on the basis of their functionality and properties. Casein proteins are acting as antiviral and immunoregulatory factors which help the human body by regulating the innate immune response both through up-regulating to increase the killing of virus and down regulating to reduce determinatal conditions such as sepsis. Like casine proteins, why proteins and peptides have been studied extensively for antiviral property.

It is believed that milk protein determines the growth and health of children. Keletzko et al. stated that CMP (cow's milk protein) is the leading cause of food allergens infants and children younger than 3 years. This condition prevents children from taking of many essential amino acids that are for body development. Vitamin D, on the other hand has a big health problem if is not adequate in the diets. Bueno AL and Czepielewski MA, noted that results in short stature and is characterized by deficiency of a micronutrient is rickets caused by Vitamin D deficiency. However, if children access a variety of diet rich in Vitamin D, they will have better body growth (development). In line to this, Gordan $\mathrm{CM}$ et al, revealed that Vitamin D is essential during childhood and adolescence.
Normal serum Vitamin D levels determine absorption of $30 \%$ of dietary calcium and more than $60-80 \%$ during growth period, due to the high demand for calcium. This is why Vitamin D deficiency during childhood can cause delayed growth and bone abnormalities, as a result increasing the risk of fractures of bone. Hence vitamin D is a basis for functionality of calcium in the human body.

Naturally, there are some sources of Vitamin D. Few of them are egg yolk, liver, butter and milk but they are eaten in less amount because of the high level of cholesterol. Another source may be from sunlight. Likewise, protein can be found from animal and plant sources although mostly animal protein is not sufficiently consumed in developing countries. Hence people in low income areas cannot afford to get animal protein rather they can use plant proteins in replace to animals. Comparably vitamin D is found in animal protein a reasonable amount than plants proteins. This may affect the growth of children living in developing countries.

\section{Acknowledgment}

None.

\section{Conflict of Interest}

No conflict of interest. 